Stepan Ivanyk

\title{
Mirona Zaryckiego koncepcja relacji matematyki i estetyki
}

Koniec XIX oraz pierwsza połowa XX wieku, to złoty wiek rozwoju kultury i nauki polskiej we Lwowie. Jednak często się zapomina, że rozwojowi temu towarzyszył ściśle z nim związany w tym mieście również rozwój kultury i nauki ukraińskiej. Nie sposób zrekonstruować całościowego obrazu ówczesnego życia intelektualnego Lwowa, w szczególności w dziedzinie filozofii, bez uwzględnienia roli obu tych pierwiastków narodowych ${ }^{1}$. Celem niniejszego artykułu będzie, chociażby częściowe zapoznanie polskich badaczy z jednym z tych aspektów rozwoju filozofii w przedwojennym Lwowie, która obecnie w Polsce jest prawie nieznana, a jednakże warta jest uwzględnienia. Cel ten zrealizowany zostanie poprzez przedstawienie oryginalnej koncepcji relacji matematyki i estetyki jednego z najbardziej znanych ukraińskich matematyków i filozofów działajacych w tym okresie we Lwowie - Mirona Zaryckiego. Interesująca wydaje się kwestia, w jaki sposób poprzez analizę teoretycznej, praktycznej i estetycznej wartości matematyki, Zarycki uzasadnił tezę o tym, że ta ostatnia jest wartością naczelną królowej nauk.

\footnotetext{
${ }^{1} \mathrm{~W}$ życiu intelektualnym Lwowa liczyli się również Żydzi, Niemcy (Austriacy), Czesi, Ormianie, Rosjanie i inne narodowości.
} 


\section{Miron Zarycki}

Zacznijmy od krótkiego przedstawienia życia i twórczości Zaryckiego. Urodził się on 21 maja 1889 roku na wsi Mohylnica w powiacie trembowelskim Galicji Wschodniej. W 1907 roku ukończył Ukraińskie Gimnazjum w Przemyślu i rozpoczął studia na Wydziale Filozoficznym Uniwersytetu Wiedeńskiego, kontynuowane od roku 1908 na Wydziale Filozoficznym Uniwersytetu Lwowskiego. Na studiach we Lwowie skupił się głównie na matematyce (brał udział w seminariach Józefa Puzyny i Wacława Sierpińskiego), ale żywo interesował się też filozofią (uczęszczał między innym na wykłady Kazimierza Twardowskiego). W 1912 roku Zarycki ukończył uniwersytet i następnie pracował jako nauczyciel matematyki w ukraińskich gimnazjach: Bełżcu, Zbarażu, Kołomyi i Tarnopolu. W 1925 roku na zaproszenie Hugo Steinhausa przeprowadził się do Lwowa, gdzie prowadził aktywną działalność naukową. W tym okresie Zarycki uczęszczał też na uniwersyteckie wykłady „Sylogistyka” i „Wstęp do psychologii” Twardowskiego ${ }^{2}$ i współpracował z czasopismem Ruch Filozoficzny, redagowanym przez założyciela filozoficznej Szkoły Lwowsko-Warszawskiej. W 1930 roku uzyskał w Uniwersytecie Lwowskim tytuł doktora filozofii, na podstawie rozprawy „Niektóre główne pojęcia teorii przestrzeni z punktu widzenia algebry logiki” ${ }^{3}$. O tym ostatnim wydarzeniu znajdujemy wzmiankę w "Dziennikach" Twardowskiego:

25 października, sobota 1930

O dwunastej poszedłem do Auli, by złożyć życzenia z powodu promocji p. Zaryckiemu, byłemu uczniowi mojemu, który mnie na promocję zaprosił ${ }^{4}$.

${ }^{2}$ Zob. Archiwum Tarnopolskiego Muzeum Krajoznawczego, sygnatury ТКМРД-500, ТКМРД-503.

${ }^{3}$ Zarycki M., „Quelques notions fondamentales de l'Analysis Situs aux point du vue del'Algébre de la Logique", Fundamenta Mathematicae, T. XI, 1927 , s. 3-15.

${ }^{4}$ K. Twardowski, Dzienniki, Cz. II. 1928-1936, Wydawnictwo Adam Marszałek, Warszawa-Toruń 1997, s. 168. 
We Lwowie Zarycki wykładał matematykę w Ukraińskim Gimnazjum oraz w Polskim Gimnazjum im. K. Szajnochy ${ }^{5}$.

W 1927 roku został wybrany na członka Towarzystwa Naukowego im. T. Szewczenki, a w 1930 roku - Polskiego Towarzystwa Matematycznego i Niemieckiego Towarzystwa Matematycznego ${ }^{6}$ Po zajęciu Galicji Wschodniej przez Związek Sowiecki w 1939 roku zaczął pracę na Uniwersytecie Lwowskim, gdzie w 1945 roku zastąpił Stefana Banacha na stanowisku dziekana Wydziału Fizyczno-Matematycznego. Zmarł w 1961 roku.

Większość prac naukowych Zaryckiego to prace sensu stricto matematyczne; publikował też przekłady (np. z francuskiego na

\footnotetext{
${ }^{5}$ Interesujące jest, że w Gimnazjum Szajnochy wśród uczniów Zaryckiego był Stanisław Lem, który w swoich wspomnieniach pisał o nim: „Matematyki uczył profesor Zarycki, jedna z bardziej niezwykłych postaci ciała pedagogicznego, Ukrainiec, którego córka była wmieszana w sprawę zamachu na ministra Pierackiego. (...) Baliśmy się go okropnie, ja także, matematyka zawsze bowiem była moją piętą achillesową. Nasz matematyk poczynał sobie z nami w sposób dosyć niezwyczajny, albowiem miewał fantazję. Czasem nagradzał za dobrą odpowiedź w ten sposób, że kazał wyróżnionemu opuścić klasę i spacerować sobie po mieście; to znów zaczynał lekcję od tego, że wyrwanych z ławek uczniów rozsyłał pod rozmaite adresy, ażeby mu pozałatwiali to i owo. Było to wyróżnieniem, bo wszak w sposób wyjątkowo bezpieczny wyłączało z kręgu niebezpieczeństw czających się przy zapaskudzonej kredą tablicy (...). Zarycki był groźny, bo zagadkowy - nie umieliśmy nigdy zorientować się, kiedy żartuje, a kiedy czegoś żąda serio" (S. Lem, Wysoki zamek, Agora, Warszawa 2009, s. 68-69). Za rozwiązanie szczególnie trudnego zadania Zarycki miał zwyczaj nagradzać swoich uczniów cygarem. Sprezentowane w taki sposób przez Zaryckiego cygaro, Lem długo przechowywał jak cenną „relikwię”. Wsród profesorów tego Gimnazjum byli nb. również Roman Ingarden i Iwan Krypiakewycz (wybitny ukraiński historyk). Ten ostatni napisał w swoich wspomnieniach: „Spośród nauczycieli [gimnazjum] byli niektórzy sympatyczni: Miron Zarycki wizytatorom imponował tym, że teoremat Pitagorasa wyjaśniał po grecku (...). Umiał sobie ułatwiać pracę (od niego pochodzi teoria: złączyć dwie klasy i puścić do domu”) I. Крип'якевич, „Спогади (Автобіографія)” [w:] Я. Ісаєвич (red.) Іван Крип'якевич у родинній традищї̈, науці, суспілъстві, Lwów 2001, s. 124.

${ }^{6}$ Zarycki był znany we Lwowie pod przezwiskiem „ostatni Szkot”, które pochodzi od nazwy słynnej lwowskiej Kawiarni Szkockiej, w której zbierali się lwowscy matematycy.
} 
ukraiński Kurs analizy funkcjonalnej Banacha). Do dzieł filozoficznych Zaryckiego należy natomiast zaliczyć:

A. W języku ukraińskim:

1. „Prawda, piękno, matematyka” (Lwów 1927);

2. „Problem matematycznej prawdy i piękna myśli matematycznej" (Lwów 1941-1944)

3. „Matematyka z punktu widzenia materializmu dialektycznego";

4. „Metoda aksjomatyczna w matematyce”;

5. „Światopogląd matematyczny" ${ }^{\text {. }}$

B. W języku polskim:

1. „Metageometria i jej znaczenie dla teorii przestrzeni Kanta” [recenzja] (Lwów 1929);

2. „Antologia matematyki greckiej” [wstęp do wyboru pism] (Lwów 1933).

C. W języku francuskim:

1. „Niektóre główne pojęcia teorii przestrzeni z punktu widzenia algebry logiki" (1927).

Problemowi wzajemnego stosunku estetyki i matematyki poświęcony jest artykuł Zaryckiego „Prawda, piękno i matematyka” $(1927)^{8}$ oraz jego odczyt na posiedzeniu „Wydawnictwa Ukraińskiego" 9 pod tytułem „Problem prawdy matematycznej i piękna

${ }^{7}$ Pozycje 2-5 zachowały się w rękopisach w domowym archiwum Zaryckiego we Lwowie

${ }^{8}$ М. Зарицький, ,Правда, краса і математика" [w:] Maтематика серед наук, Lwów 1927, s. 25-37.

${ }^{9}$ Wydawnictwo Ukraińskie - to ukraiński ośrodek wydawniczy, istniejący w latach 1939-1945 w Krakowie i Lwowie. 
myśli matematycznej" (1941-1944) ${ }^{10}$. W pracach tych Zarycki stawia sobie za cel obalenie rozpowszechnionego poglądu, zgodnie z którym:

(1) podstawową wartością matematyki jest wartość praktyczna (tkwi ona w szerokich możliwościach zastosowania jej w sferze praktyki);

(2) matematyka posiada też wartość teoretyczną (jest nią absolutna pewność i prawdziwośćc ${ }^{11}$ jej twierdzeń), podrzędną w stosunku do wartości praktycznej;

(3) matematyka nie posiada natomiast żadnej wartości estetycznej (nie stosuje się do niej kategoria piękna).

\section{Teoretyczna wartość i cel matematyki}

Zbadanie kwestii teoretycznej wartości i celu nauki wiąże się $\mathrm{z}$ analizą zagadnienia prawdy w matematyce. Zarycki rozpatruje rozpowszechniony sposób traktowania matematyki jako nauki par excellence dedukcyjnej, która zawiera wyłącznie sądy w oczywisty sposób prawdziwe i dotyczy wyłącznie pojęć, które są ściśle zdefiniowane; jako jedynej nauki, która ma prawo wymagać bezwzględnej wiary w swoje twierdzenia. W celu podważenia tego przekonania Zarycki przytacza twierdzenie Russella, że w matematyce nigdy nie wiemy (1) o czym mówimy, ani (2) czy to, o czym mówimy, jest prawdą.

Zarycki podaje następujące argumenty na rzecz tego twierdzenia:

Ad (1). Nie sposób podać ścisłej definicji podstawowych pojęć matematycznych, przy pomocy których definiujemy wszystkie inne pojęcia matematyczne. Ażeby zdefiniować jakiekolwiek pojęcie,

\footnotetext{
${ }^{10}$ М. Зарицький, Проблемаматематичной правдиикрасиматематично $\ddot{~}$

${ }^{11}$ Chodzi tutaj o korespondencyjne teorie prawdy jako zgodności twierdzenia z rzeczywistością.
} 
musimy się odnieść do pojęcia o szerszym zakresie (genus proximum), a żeby zdefiniować to drugie, musimy się odnieść do jeszcze ogólniejszego pojęcia itd. - w końcu dochodzimy do najogólniejszych pojęć (universalia), których już nie da się w ten sposób zdefiniować. Na przykład: kwadrat - to czworobok równoboczny i prostokątny, czworobok - to zbiór punktów na płaszczyźnie, ograniczony czterema prostymi. Zatem widać, że aby wiedzieć, co to jest kwadrat, musimy wiedzieć, co to jest punkt. Jednakże współczesna matematyka nie posiada zadowalającego określenia pojęcia punktu, podobnie jak pojęć liczby, wielkości, zbioru, równości, porządku itd. Jeśli zaś nie znamy istoty tych podstawowych pojęć matematycznych - nie znamy też istoty wszystkich pozostałych definiowanych przez nie pojęć matematycznych. Wolno więc powiedzieć, że nie wiemy, o czym mówimy w matematyce.

Według Zaryckiego odpowiedzi na pytanie, o czym mówimy w matematyce, należy szukać raczej w epistemologii lub metafizyce - nie zaś w samej matematyce. Powyższymi kwestiami zajmuje się dyscyplina leżąca na styku matematyki i filozofii filozofia matematyki, w ramach której wyłoniły się główne rywalizujące ze sobą nurty: logicyzm, formalizm i intuicjonizm. Dążenie do wyjaśnienia kwestii epistemologicznej genezy podstawowych pojęć matematycznych Zarycki rozumie jako środek pomocniczy, zwiększający szanse matematyka na osiągnięcie sukcesu w swojej dyscyplinie.

$A d(2)$. Nie sposób stosować kryterium prawdziwości do aksjomatów matematycznych, na których opierają się wszystkie twierdzenia matematyczne. Aksjomaty, wbrew powszechnej opinii, wcale nie są prawdami oczywistymi, a tylko dowolnie (hipotetycznie) przyjętymi sądami, które nie są ani prawdziwe, ani fałszywe (np. geometria euklidesowa i nieeuklidesowa są oparte na wykluczającysh się ze sobą układach aksjomatach). Skoro zaś do aksjomatów nie da się stosować kryterium prawdziwości, to i oparte na nich teorematy nie moga rościć sobie pretensji do absolutnej prawdziwości. 
Matematyka jest zbudowana z twierdzeń o postaci „z hipotezy $X$ wypływa konsekwencja $Y$ ", co znaczy, że absolutna prawda matematyczna jest prawdą tylko w sensie formalnym (czyli jej prawdziwość jest jedynie pochodną zgodności logicznej z przyjętymi z góry aksjomatami), a nie w sensie materialnym (tj. na podstawie zgodności tej prawdy z rzeczywistością). Stąd: w matematyce nigdy nie wiemy, czy to, o czym mówimy, jest prawdą (w sensie materialnym).

Zarycki konkluduje więc, że prawda (materialna) nie jest ani kryterium wartości matematyki ani jej celem:

Czystego matematyka nie interesuje realna treść jego pojęć; pojęcia te są [dla niego] tylko znakami, symbolami, i rozpatruje on tylko te ich cechy, które sam im przypisuje w dobranych przez siebie aksjomatach, [ze względu na co] abstrakcyjna matematyka jest wolnym wytworem ducha ludzkiego, oderwanym od obiektywnego doświadczenia ${ }^{12}$.

\section{Praktyczna wartość i cel matematyki}

W świetle powyższych rozważań nasuwa się jednak pytanie: Skoro matematyka jest nauką badajaccą nierealne obiekty i oderwaną od obiektywnej rzeczywistości, to jak wyjaśnić niezaprzeczalny fakt, że jej konstrukcje znałazły tak znakomite praktyczne zastosowania (m.in. stały się podstawą techniki i przyrodoznawstwa)?

Odpowiedź Zaryckiego brzmi następująco: z perspektywy historycznej aksjomatyzacja każdej dyscypliny matematycznej zawsze jest końcowym etapem jej rowoju; metoda aksjomatyczna tylko porządkuje i uściśla wzajemne relacje logiczne między pojęciami i buduje harmonijną całość z teorematów, wywodzących się z praktycznych potrzeb człowieka. W szczególności, podstawowe pojęcia matematyczne (liczba, forma, wielkość i in.) - to, zgodnie

\footnotetext{
${ }^{12}$ M. Зарицький, Проблема математично $\ddot{~}$ правди и краси математично ̈̈ думки, Lwów 1941-44.
} 
ze stanowiskiem naiwnego realizmu, nieodłączne cechy przedmiotów obiektywnego świata, w pewnym momencie wyabstrahowane z samych tych przedmiotów.

Mimo tego praktyczne stosowanie nie jest kryterium wartości twierdzeń matematycznych i celem matematyki.

Do takiej konkluzji Zaryckiego doprowadza, po pierwsze, rozbiór mechanizmów stosowania matematyki w fizyce. Zarycki wyróżnia tutaj następujące etapy.

Etap (1): fizyk ujmuje otrzymane drogą indukcyjną (przy pomocy obserwacji i eksperymentu) kwantytatywne prawa przebiegu zjawisk fizycznych w formułach matematycznych. Etap (2): matematyk bada przyjęte przez fizyka równania matematyczne i wyprowadza z nich inne. Etap (3): fizyk dokonuje fizykalnej interpretacji wyprowadzonych przez matematyka równań, w wyniku czego otrzymuje nowe prawa fizyki.

W ten sposób wyjaśnia się istota stosowania matematyki w fizyce: fizyk wysuwa nowe problemy matematyczne, a matematyk odkrywa nowe prawa fizyki. To „odkrywanie praw fizyki” samo w sobie nie jest jednak właściwym celem matematyka:

Kiedy matematyk opracowywuje jakiś fragment matematycznej teorii przyrodoznawstwa [na etapie (2)], to jest oczywiste, że myśli on wtedy wyłącznie o swoich abstrakcyjnych symbolach, podobnie jak autor dobrego panegiryku w czasie jego tworzenia nie myśli o honorarium, lecz tylko o pięknie swojego poematu ${ }^{13}$.

Odkryte przez Archimedesa w III wieku p.n.e. cechy paraboli i elipsy dopiero po stuleciach zostały zastosowane w mechanice, a neeuklidesowa geometria Łobaczewskiego (pierwsza połowa XIX wieku) dopiero w XX wieku została zastosowana do nowych teorii fizykalnych.

Po drugie, porównanie ilościowe stosowanej i teoretycznej (czystej) części matematyki, pokazuje, że tylko nieliczne pojęcia i teorie

${ }^{13}$ Tamże. 
matematyczne znalazły zastosowanie praktyczne. W zdecydowanej większości wypadków matematyka tworzy „niepraktyczne” abstrakcje, które co najwyżej mogą być zastosowane praktycznie w mniej lub bardziej odległej przyszłości.

Zarycki podsumowuje swoje rozważania w następujący sposób:

Matematyk przy budowie swoich subtelnych konstrukcji logicznych nie może się oglądać na żadne cele utylitarne. W swej pracy twórczej widzi on przed sobą tylko jeden cel, a mianowicie matematykę jako naukę dla nauki, sztukę dla sztuki ${ }^{14}$.

\section{Estetyczna wartość i cel matematyki}

Żeby wyjaśnić kwestię estetycznej wartości matematyki, należy najpierw odpowiedzieć na pytanie, co to jest piękno i sztuka, oraz co to jest dzieło sztuki (tj. źródło zadowolenia estetycznego). Zarycki rozważa dwa przeciwstawne stanowiska w teorii sztuki, będące odpowiedziami na te pytania:

(1) Zgodnie z obiektywistyczną teorią sztuki - piękno tkwi w zjawiskach fizycznych, w realnych faktach, które wywołują w świadomości człowieka zadowolenie estetyczne („emocje estetyczne").

(2) Zgodnie z subiektywistycznj teorią sztuki - piękno tkwi w zjawiskach psychicznych człowieka, przeżywającego zadowolenie estetyczne.

Zarycki analizuje próbę wskazania obiektywnych kryteriów dzieła sztuki na przykładzie utworów muzycznych. Ich obiektywnym korelatem są specyficzne fale powietrzne, których różnorodne kombinacje wywołują poprzez narządy słuchowe pewne zmiany

${ }^{14}$ Tenże, ,Правда, краса и математика" [w:] Maтематика серед наук, Lwów 1927, s. 27. 
chemiczne w układzie nerwowym człowieka, po których znów następuje psychiczna percepcja oddzielnych tonów oraz złożonych współbrzmień i melodii. Każdy akord muzyczny, jako pewnego rodzaju kombinacja fal powietrznych, może być ujęty w odpowiedniej formule matematycznej (pianista $\mathrm{z}$ wykształceniem matematycznym mógłby np. zagrać każdy akord mając przed sobą zamiast nut takie formuły). Badania teoretyków sztuki, zgodnie z obiektywistyczną teorią piękna, mogłyby w związku z tym polegać na sprawdzaniu i porównywaniu, jakim formułom odpowiadają piękne symfonie, a jakim - kabaretowe kakofonie. Takie badania jednak są według Zaryckiego bezsensowne:

Zjawiska fizyczne w chwili grania na instrumencie i wytwarzane przez nie zjawiska psychiczne sa zjawiskami toto genere różnymi; jest między nimi przepaść, której nie wyjaśni żadna spekulacja. Gdybyśmy nawet poznali w najdrobniejszych szczegółach wszystkie wywoływane przez fale powietrzne zmiany zachodzące w komórkach naszego organizmu, to między nimi a przeżyciem estetycznym pozostałby skok, którego nie wyjaśni żaden eksperyment i żadna metafizyka ${ }^{15}$.

W świetle powyższego Zarycki jednoznacznie opowiada się po stronie subiektywistycznej teorii piękna:

$\mathrm{Na}$ podstawowe pytanie, co jest dziełem sztuki, istnieje tylko jedna odpowiedź: dziełem sztuki jest to, co w naszej świadomości wywołuje specyficzne emocje, zwane zadowoleniem estetycznym (...). O tym, czy coś jest, czy nie jest uczuciem estetycznym, może decydować tylko sama jakość danego przeżycia psychicznego i nic więcej ${ }^{16}$.

Innymi słowy, według Zaryckiego - dziedziną sztuki są wyłącznie swoiste zjawiska psychiczne, zwane emocjami estetycznymi,

\footnotetext{
${ }^{15}$ Tепże, Проблема математично $і ̈$ правди и краси математично думки, Lwów 1941-44

${ }^{16}$ Tamże.
} 
a dziełem sztuki jest intencjonalny przedmiot świadomości, będący źródłem takich emocji: na tym właśnie polega istota sztuki i piękna.

Sam fakt powstania pozytywnego uczucia estetycznego, podobnie jak każdego innego zjawiska psychicznego, może być opisany tylko przez kogoś, kto to uczucie przeżywa aktualnie lub przeżył w przeszłości, tj. drogą introspekcji. Zarycki powołuje się na Theodora Lippsa, Mykołę Szłemkewycza ${ }^{17}$ i Johannesa Volkelta, jako na filozofów, którzy kładli nacisk na to, że dzieło sztuki wywołuje emocje estetyczne wyłącznie za pośrednictwem przedstawień naocznych (wyobrażeń), i twierdzi, że abstrakcyjne teorie matematyczne dopuszczają wiele naocznych interpretacji. Co za tym idzie - nie ma przeszkód, aby idee matematyczne mogły być źródłem emocji estetycznych. Na zarzut, że matematyka jest źródłem zadowolenia intelektualnego, a nie estetycznego (tj. że psychologiczną podstawą wywoływanych przez idee matematyczne uczuć pozytywnych jest sąd, a nie przedstawienie), Zarycki odpowiada, że kombinacje matematyczne nie są tworzone tylko przy pomocy czynnika intelektualnego (dedukcji). Ważną rolę w procesie twórczości matematycznej odgrywa też twórcza wyobraźnia - jako czynnik alogiczny. Jest tak, ponieważ aby powstała nowa teoria matematyczna, matematyk musi najpierw przy pomocy intuicji przedstawić sobie pewną nową kombinację pojęć matematycznych, a dopiero potem ją logicznie rozwinąć i uporządkować. Tak więc do powstania teorii matematycznych potrzebne jest połączenie dwóch czynników: intelektualnego (akt sądzenia) i estetycznego (akt przedstawienia). Ten fakt zyskuje u Zaryckiego potwierdzenie w jego osobistym doświadczeniu wewnętrznym, w którym dostrzega on wyraźną róźnicę między uczuciem zadowolenia, wywołanym przez odkrycie lub poznanie prawdy matematycznej, a uczuciem zadowolenia, wywołanym przez przedstawienie sobie pięknej myśli matematycznej.

${ }^{17}$ Mykoła Szłemkewycz (1894-1966) - filozof ukraiński, absolwent Uniwersytetu Wiedeńskiego (1926), uczeń Moritza Schlicka. 
Z tej racji nie ma zasadniczej różnicy między doznaniem uczucia estetycznego zadowolenia na podstawie przedstawienia melodii, obrazu czy formuły matematycznej:

Teorie matematyczne - to kombinacje pojecć reprezentowanych przez symbole; piękno ich fascynuje matematyka tak samo, jak fascynują każdego z nas harmonijne kombinacje form, utrwalone w kamiennych bryłach dzieł architektury ${ }^{18}$.

Matematyka więc pozostaje w ścisłym związku ze sztuką, co nie pozostaje bez wpływu na specyficzną strukturę psychiki matematyków, którym w ich spekulacjach matematycznych zależy nie tylko na osiągnięciu pozytywnych wyników, lecz także (a według Zaryckiego raczej przede wszytskim) na przeżyciu silnych uczuć estetycznych oraz przekazaniu tych uczuć tym, którzy są w stanie je przeżywać (na poparcie tego twierdzenia Zarycki przytacza poglądy Platona, Arystotelesa, Leonarda da Vinci, Carla Gaussa i Henriego Poincarégo). Zarycki konkluduje:

Ten, kogo nie wabi piękno i sztuka, kto żyje ubogim życiem duchowym, nic nie da matematyce ${ }^{19}$.

Skąd jednak się bierze tak mocne powszechne przekonanie, że matematyka - to sucha, pozbawiona piękna nauka, a poznanie i konstruowanie jej twierdzeń nie może dać żadnego zadowolenia estetycznego? Przyczyny tego poglądu Zarycki upatruje w tym, że dla przeżycia najprostszego uczucia zadowolenia estetycznego, wywołanego np. oglądaniem obrazu czy słuchaniem melodii, wystarczy tylko posiadanie zdrowych zmysłów. Natomiast w wypadku matematyki to nie wystarcza: tutaj niewtajemnioczonemu odbiorcy wzrok daje tylko symbole bez znaczenia, a słuch - niezrozumiałe złożenia słów. Do odebrania w sposób estetyczny obiektów matematycznych potrzebne jest długotrwale i pracochłonne wprawianie się $\mathrm{w}$ matematyce, a to się udaje tylko drobnej części

\footnotetext{
${ }^{18}$ Tenże, „Правда, краса і математика”, dz. cyt., s. 32-33.

${ }^{19}$ Tamże, s. 36.
} 
społeczeństwa; dla większości matematyka pozostaje tym samym, co „obrazy Rafaela dla ślepego lub symfonia dla głuchego” ${ }^{20}$.

\section{Zakończenie}

Wyniki analizy prowadzą Zaryckiego do negacji twierdzeń wyjściowych, będących przedmiotem jego analizy krytycznej. W szczególności jego zdaniem:

(1) Matematyka posiada dość ograniczoną wartość praktyczną (przeważnie hipotetyczne tylko możliwości zastosowania $\mathrm{w}$ praktyce).

(2) Matematyka posiada względną wartość teoretyczną (twierdzenia jej są tylko formalnie pewne i prawdziwe).

(3) Podstawową wartością matematyki jest jej wartość estetyczna (piękno).

W związku z tym:

(1) Utylitarny cel matematyki (dążenie do zastosowania w praktyce) jest co najwyżej uboczny.

(2) Teoretyczny cel matematyki (dążenie do prawdy) jest realizowany tylko pod warunkiem rozumienia prawdy $\mathrm{w}$ sensie formalnym.

(3) Podstawowym celem uprawiania matematyki jest dążenie do piękna.

Podstawową wartością matematyki jest więc, wedle Zarzyckiego, jej wartość estetyczna (piękno), a podstawowym celem cel estetyczny (dążenie do piękna).

Po rekonstrukcji jednego z najciekawszych fragmentów ukraińskiej myśli filozoficznej przedwojennego Lwowa na przykładzie

${ }^{20}$ Tепże, Проблема математично $\ddot{~ п р а в д и ~ и ~ к р а с и ~ м а т е м а т и ч н о ~} і$ думки, Lwów 1941-44. 
koncepcji relacji matematyki i estetyki Mirona Zaryckiego należałoby jeszcze pobieżnie określić znaczenie historyczno-filozoficzne owej koncepcji dla badaczy dziejów filozofii polskiej we Lwowie. Jak się wydaje, omówina wyżej koncepcja przede wszystkim powinna być rozpatrywana $\mathrm{w}$ kontekście problematyki estetycznej dyskutowanej w obrębie filozoficznej szkoły lwowskiej Twardowskiego, uczniem którego, jak pamiętamy, był Zarycki. Na przykład poglądy Zaryckiego nie tylko zadziwiająco korespondują z poglądami jednego z najwybitniejszych reprezentantów tej Szkoły, Jana Łukasiewicza, na twórczy charakter logiki i matematyki, ale też zawierają sporo interesującej argumentacji na poparcie stanowiska w tej kwestii twórcy logiki trójwartościowej. Nie bez wpływu na rozważania Zaryckiego były też zapatrywania Hugo Steinhausa na rolę pierwiastka estetycznego w matematyce ${ }^{21}$. Dokładniejsze zbadanie tego wątku jednak wykracza poza ramy niniejszego artykułu.

\section{Bibliografia:}

1. Lem S., Wysoki zamek, Agora, Warszawa 2009;

2. Steinhaus H., Czem jest a czem nie jest matematyka, Księgarnia Nakładowa H. Altenberga, Lwów 1923.

3. Twardowski K., Dzienniki, Cz. II. 1928-1936, Wydawnictwo Adam Marszałek, Warszawa-Toruń 1997;

4. Zarycki M., „Quelques notions fondamentales de l'Analysis Situs aux point du vue del'Algébre de la Logique", Fundamenta Mathematicae, T. XI, 1927

5. Зарицький М., Правда, краса i математика [w:] Математика середнаук, Lwów 1927

${ }^{21}$ Zob. H. Steinhaus, Czem jest a czem nie jest matematyka, Księgarnia Nakładowa H. Altenberga, Lwów 1923. 
6. Ісаєвич Я. (red.) Іван Крип'якевич у родиннійтрадиції, науці, суспільстві, Lwów 2001

\section{Abstract}

\section{Miron Zarycki's concept of relationship between ma- thematics and aesthetics}

The paper presents a reconstruction of one of the most interesting parts of the Ukrainian philosophical mind in pre-war Lviv on the example of Miron Zarycki's koncept of relationship between mathematics and aesthetics. According to the concept of Zarycki, a core value of mathematics is its aesthetic value (beauty), and the primary purpose - the aesthetic purpose (the pursuit of beauty).

Keywords: Mathematics, aesthetics, art 